\title{
The Importance of the Foreman's Motivation in the Implementation of High-rise Building Projects in Quality Management
}

\author{
Parlan Bobby \\ Fakultas Teknik Sipil, Jurusan Rekayasa dan Manajemen Proyek Konstruksi, Universitas Persada Indonesia Y. A. I \\ bobparlu@yahoo.com
}

\begin{abstract}
The construction goals to achieve quality work results, it can be in form of "satisfaction" to the Owner goals, although 'increasing credibility and competitiveness' for the Contractor required. In Indonesia, most of the contractors use foreman contract work to their project completion. The foreman performance will be affects to his quality. The influencing factors are Motivation, Experience and Skills, where the "Motivation" is to the top level. Motivation is an individual's drive to do something. If the Contractor can be predicted at the beginning how the foreman's motivation to decrease, these causes can be controlled. This research program was conducted to find out how much influence there between the decrease in foreman's motivation to the performance was disrupted to the quality standard (Quality Pass). The foreman's motivation are to be taken as the independent variable X.3 (three) dependent variables (Y) will be used in this research based on quality standards (Quality Pass), as "Customer Satisfaction", "Performance to Customer Requirements" and "Fitness for use. The methodology used a regression with multiple linear analysis. Researcher used 51 sampling consist of Task the Owners, Contractors and Consultants who were directly involved in Graha Pertamina. Based on the result, the dominant factors which to affect for the foreman motivation decreased that the quality standard was not achieved, consist of 1) After the manpower has received their salary, they were asked for leave permission with his supervisor in the wrong time, so the target is not achieved, 2) when the materials/tools was needed, in fact, it is not available in the field.3) The Covid 19 pandemic more then one years in Indonesia that has caused the wholesale price not to increase, but the supply demand of workers goes up. The strategy must to do for increase the foreman motivation on construction project that the Contractor must maintain and improve his ability to organize their scope of works.
\end{abstract}

Keywords: Foreman motivation, Quality PASS criterion, High Rise Building Construction Project

\section{Background}

The construction world in Indonesia is currently growing rapidly, the competition conditions in the construction world today to be increasingly tight. Many industries have grown up as a result of increasing and varied human needs (Soedjito, 2012). Everyone who involved in the construction sector, wants to his graphic business experience will be increased every time. To achieve that, it is certainly not easy, good management is important to a business to achieve performance goals and effort to increase the profit.

Kariman (2017) said one of efforts to achieve the company's performance improvement is determined by the project management team and they must know how to handle the project to starts from planning, controlling and supervision that to do the project works and to minimize of the project failure risk.

The project failure for construction industry in Indonesia case, one of them due to the construction implementation is not in accordance with the quality standards. It indicates that there is still low concern for construction implementation to realizing the expected quality achievement.

The achievement of quality during the construction projects period, it can take place well, if a supporting factors in the motivation from human resources arise, so the key success of a project are discipline, time and quality can be realized. The owners and contractors in a project need to set up a building quality acceptance standard through assessment process (Quality Product Assessment System - QPASS) that represents a work quality value.

Quality Product Assesment System or QPASS was developed to calculate of project quality level achievement, while the workers motivation is the one of an important factors that can affect productivity in a construction project. Motivation relates to a person's willingness to work. Motivation encourages a person or group to do a job by trying to fulfill a desire or give another attraction (Soeharto, 1995). Anugrahni (2013), said unmotivated person, only gives minimum effort in working terms and motivation is closely related to the continuity of work that is being done by the man power.

This research is limited to personalize who works in environment to the PT. Wijaya Karya Bangunan Gedung at Graha Pertamina Project in Jakarta. There are some interesting problems to be examined more deeply, among others:

1) The defect in the works step often occur and become a recurring problem. How can a worker's performance in accordance with quality standards based on the assessment score ( $Q$ - Pass), that is very important during construction period, especially for 'fast track' condition, in order to avoid bad workmanship?

2) What are the motivational factors that cause manpower (Foreman) motivation to decrease, so it is resulting in the work quality does not accordance with the Q - Pass standard?

3) What is the effect between the decrease in foreman's motivation during the construction period with a non achievement of quality standards (Q - Pass) who desired 
by the Owner?

The problems above are a frequent case in the construction project environment. Although the foreman has been certified (expertise), not necessarily the foreman and manpower can complete the work in accordance with Q Pass standards, because the foreman performance is indirectly influenced by the work motivation and commitment for the target completion.

This research is to analyze the decrease in Foreman motivation during the construction period and the non achievement of quality standards (Q - Pass) desired by Owner.

\section{Theory}

\section{Construction - High Rise Buildings}

Construction projects are activities that are only one time implemented and generally short - term period. In the activities, that there is a process to project processes resources into building activities. The activities process involves related parties as directly or indirectly. The construction projects characteristics are seen in three dimensions as an unique, involving a resources and requires organization. In the completion process must be in accordance with the specifications, especially the quality/quality of products was produced in accordance with the scope of contract.

\section{Works Motivation}

Motivation is a concept that encourages individuals, in order to work well, and more excited and enthusiastic in order to achieve the goals, where the driving force is a wish to the individual needs.

\section{Theory of Motivation}

Motivation theory can be classified as a satisfaction theory or a process. The one of the satisfaction theories that are widely used, namely Maslow's theory of need. This theory put forward by Abraham Maslow and he said that the human has motivated to satisfy a lot of needs inherent to each individual. Maslow distinguishes human motives based on his needs level (Handoko, 1992). Ervianto (2005) said Human beings have needs that are hierarchically ranked, the most basic of Maslow's needs are physiological needs. once a lower - level need is satisfied, it no longer serves as a motivator.

There have a five classification of needs theory, it based on strength, potential and urgency. For potential and the urgency insistence is will be placed on the top level (Hidayat, 2009). Each level will affect to human resources behavior. Hidayat said the fulfillment of the different needs people will depend on the job description, age, race, and organization.

In general, most people will be along their need from one level to another level sequentially. The needs theory referred to:

a) Physiological needs, is a basic of physical human needs and support human survival such as: food, drinks, shelter, and clothing. If these needs are not fulfilled, it will be more feels then compared to other needs. An individual who has nothing in life, is likely to be motivated by these physiological needs (Winardi, 2001). In its application, the needs are usually met through wages or salaries provided by workplace organizations

b) Safety Needs, is once an individual's physiological needs are satisfied, the needs for security and safety become salient. People want to experience order, predictability and control in their lives. If the physiological needs are sufficient, for the next level are higher and the security needs begin to dominate for human behavior (Winardi, 11, 2001).

c) The fulfillment of these needs is usually done by workplace organizations such as providing life insurance, Jamsostek, health insurance, health and medical benefits, additional benefits, and job security.

d) Social or affiliation needs, is the needs to be accepted in community groups (Ervianto, 2005). Humans need to interact with each other. In the organization, this need influences desire to have good relationships with fellow workers as well as with superiors, groups participation, and a working atmosphere where members can give and receive from each other.

e) Exteem needs, is needs related to the desire to have a positive impression and receive attention, want to feel valued and appreciated by others in a relationship, feeling valued and valued by others in a relationship, and want to get recognition from others. The need for the award includes needs related to a person's reputation, status, recognition and appreciation of himself (Winardi, 2001). These needs can be met through awards, feedback from superiors, and promotions (Krisdiana, 2012). In an organization, award can motivate an individual to increase responsibility and high status.

f) Self - actualization needs, is an actualize needs to himself into a job, where he will give a distinctive feature to his work (Ervianto, 2005). Putri (2012) said the important need is the need for self - actualization, where the need will never be satisfied. If one of self actualization needs has been satisfied, then there will be an actualization need for the other self. It can lead to an individual's motivation to increase in developing their potential and competence. The self - actualization need can be found in organizations that provide a person to grow, to be creative, and training for challenging assignments and upgrades (Prajawardhana, 2011). Maslow said from the five categories of needs are further differentiated into two major categories such as physiological and safety needs to be lower - order needs category, while social, exteem, and self - actualization needs to be higher - order needs.

\section{Factors That Influence Motivation}

According to Gouzaly (2005), motivational factors can be grouped into two internal and external factors. Internal factors consist of personal maturity, education level, personal desires and expectations, needs, fatigue, and boredom. External factors consist of a pleasant work environment, compensation level, good supervision, appreciation for achievements, status and responsibilities. J. Ravianto (1987) said factors that can influence work motivation are: employers, colleagues, physical facilities, policies and regulations, money and non - money service 
rewards, types of work and challenges.

The activities dedication is a management functions in providing inspiration, encouragement and encouragement to workers, that workers do activities voluntarily according to what is desired by the supervisor and the workers are more eager to carry out their tasks. It is smore effective. (Manullang, 1996).

Martoyo (1987) said employees wishes are basically "built in" in three groups of human needs are as follows:

a) Good salary / wages

b) Secure jobs

c) Solid co - workers

d) The work appreciation carried out

e) Meaningful work

f) Opportunity

g) Safe, comfortable and attractive working conditions

h) A fair and wise leader

i) Reasonable direction and instruction

j) Organization is appreciated by the community.

\section{How to Know Worker's Motivation at Work}

Handoko (1992) said if you want to know that someone had motivated or not to complete a job, it can be done in two ways: a. Measuring certain external factors that are thought to give rise to a person's inner self

b. Measure certain behavior aspects that may be the motive expressions. The right ways to find out a person's true motives is to observe the objects that are the attention center, the objects names are always pursued, sought, noticed more than others (Handoko, 1992).

\section{Relationship between Motivation and Performance (foreman)}

In the Indonesian dictionary, Performance is achieved or visible work performance. Ervianto (2005) said performance is a work result to achieved by a person in carrying out the tasks assigned to him based on skill, experience, earnestness, and time. Mangkunegara said the factors that affect performance are ability factors and motivation factors. The performance a company seeks from a person depends on the ability, motivation, and individual support received (Mathis, 2001). Mangkunegara (2012) said there is a positive relationship between motivation and performance. Highly motivated employees tend to perform well, while workers who have a low performance are possible because of their have a low motivation.

\section{Construction Workers (Foreman)}

Poerwadarminta (1985) defines a foreman as the leader or supervisor of workers. Zen (1997) revealed that one IBRD report described the foreman as "a sub - contractor of labor that employs and supervises the workforce" (a labour sub contractor who hires and supervises labours).

Zen (1997) said that foreman is an entrepreneur and contractor for the procurement as well as the certain portions completion of work. Cheng, $\mathrm{Li}$ and Love (2000) said the subcontractor as one of the participants in the project must be able to partner with other participants. Furthermore, they said that there are ten factors that affect parenting. These factors include the adequacy of resources. Gao, Smith dan
Minchin (2002), said there are seventeen factors that affect for the small - scale projects success. This factor is the adequacy of resources.

Zen (1997) reveals that the foreman coordinates much of the construction workforce $95.63 \%$ of the construction workforce are artisans and menial workers who are generally under the foreman. Soendaroe (2000) said that construction foreman in Jakarta can coordinate a workforce between 30 to 200 people.

Although his role is important in the construction implementation, but the foreman has not been able to empower himself. There is no professional association of foreman who can play an active role in improving expertise. Government agencies that handle training for construction services workforce (Puslatjakon, Kimpraswil Department) were only be able to certify a total amount of 9, 626 people until the end of December 2002 even though their number reached 55, 000 people. This means that only $17.5 \%$ of foreman is recorded, whereas according to the regulations, every construction worker must have a certificate. The the foreman position is under the field coordinator who works from the contractor.

\section{Foreman Characteristics}

The foreman role is very important in the physical implementation of field projects, most of which still rely on labor. The foreman is a potential labor force that will be determined for the work quality.

\section{Duties and Responsibilities of the Foreman}

The duties and responsibilities of the foreman in the construction project are as follows:

a) Position in the organizational structure, directly responsible to the implementer, and direct management of the workers.

b) Carry out all the implementation of the work in accordance with the instructions given by the executor and or the above ranks.

c) Maintain and keep all the company's discretion on the ground to other parties (external parties/ Extern), in all forms and at the right time.

d) Strive to the maximum to help the company in its efforts to achieve timeliness targets, quality accuracy and cost accuracy.

e) Firing and recruiting workers and craftsmen.

f) Propose to the executor to carry out overtime activities, for reasons that are acceptable to all parties who should not refuse if retained by the executor for melting work without a good reason. Overseeing the project on the field.

g) Supervise the material goods use.

h) Responsible for everything related to the project.

i) Make a report on all existing project developments and submit it to the Executor.

\section{Quality Product Assessment System Q - PASS}

Quality Product Assessment System (Q - Pass) is an assessment of several predefined paremeters, on a standard of acceptable results from a work stages series. Sampled from several parts, assessed by a Quality Control officer and then cast by weight. Then it is summed and the value must 
meet a predetermined standard value. Standard value setting is determined by Quality Assurance and learning from experience on previous project. Quality is subjective, with the notion of quality being to the degree which a set of inseparable characteristics meets the requirements.

\section{Methodology}

\section{Location and Time of Research}

This research was conducted on the Pertamina Graha Building Development Project. The project site is in Central Jakarta. Research will be conducted in approximately 6 months starting from preparation, field survey, data analysis to the preparation of research results.

\section{Data Collection Techniques}

The data collection technique in this study is a questionnaire in the form of a statements number that must be responded to by workers as respondents. Variable $\mathrm{X}$ is measured using questionnaires that contain several questions. Each statement is assigned a value of 5 alternative answers that will be weighted using the Likert scale assessment method 1 - 5 .

The five weights are:

$1=$ for a Strongly Agreeable answer (SS) $2=$ for agreed answers (S) $3=$ for neutral answer $(\mathrm{N})$

$4=$ for a Disapproval answer (TS) $5=$ for a strongly disagreed answer

The total score obtained from this scale shows that the quality management supervision system is highly influential on construction work.

\section{Methods of Research Implementation}

\section{1) Correlation Analysis}

In this study was conducted to measure the strength of dependent variables relationship foe foreman work motivation taken as a free variable $\mathrm{X}$ and quality standard (Quality Pass) as variable Y divided into 3 (three) parts: K. Ishikawa said, Quality is "Customer Satisfaction", according to P. B. Crossby, Quality is "Performance to Customer Requirement" and according to J. M Juran, Quality is "Fitness for use". Correlation analysis is used with correlation methods used if the sample data of this study is more than 30 data (large sample) and the data conditions are normal and the data studied including parametric static.

\section{2) Intercorrelation Analysis}

The process will be determined with the magnitude of the intercorrelation relationship between one independent variable to another independent variable.

\section{3) Factor Analysis}

Factor analysis aims to group variables according to their characteristics. This aims to double check whether the variables in accordance with the den remain grouped such as the group of factors in the questionnaire. In addition, simplifying the number of independent variables that have an inter correlation value $r>0.800$ needs to be grouped that the resulting model is more stable to factor $\mathrm{X}$. This is done factor analysis.

\section{4) Determinant Variables Analysis}

This analysis is intended to obtain determinant variables that affect the motivation of the Borongan foreman against quality standards ( $Q$ pass). This variable is selected from the results of grouping obtained from the analysis of factors, the grouping value of coefficient $r>0.800$ from the results of correlation analysis and $\mathrm{r}<0.800$ for the results of intercorrelation analysis, which is then selected each one variable that represents each factor.

\section{5) Multiple Linear Regression Analysis Multiple} regression analysis is done to analyze the relationship between one affected variable based on factors $\mathrm{X}$ and $\mathrm{Y}$.

\section{6) Validity Test}

In this validity test that will be used in measuring the accuracy of the items in the questionnaire. Validation for these items can be seen by correlated the existing variables. From these calculations obtained a correlation coefiesien that can be used in measuring the validity level of an item as a determinant of whether an item is feasible or not used in validity testing techniques.

\section{7) Reliability Test}

This reliability test is made to find out the consistency of the measuring instrument used can be appropriate and consistent if the measuring is done repeatedly. This study is planned to use Cronbach's alpha method which is the result of a reliability test can be seen in the output statistical reliability to give the conclusion of the measuring instrument reliability or not.

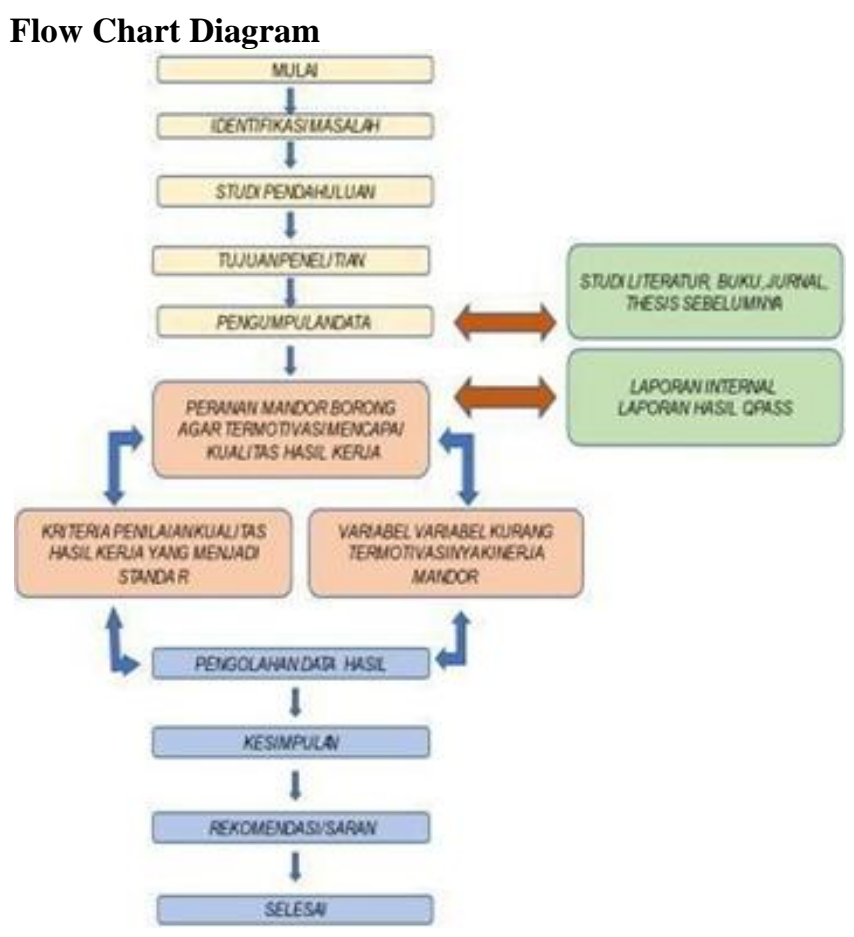

\section{Results and Discussions}

\section{Analysis of Respondent Data}

The tool used as a data collector in this study is a cookie, where questionnaires are distributed as many as 60 copies. The questionnaire is distributed to be filled by experts who work on construction projects. The construction project that 
was used as an object in this research was the Graha Pertamina Office Building Development project.

In this research has distributed of 60 copies of the kueisioner, kueisioner returned as many as 51 copies. Thus the spreading kueisioner has a response rate of $85 \%$.

Data obtained from the questionnaire is then analyzed to find out the data of expert status and work experience. The results of the respondent data analysis are presented in the following three tables:

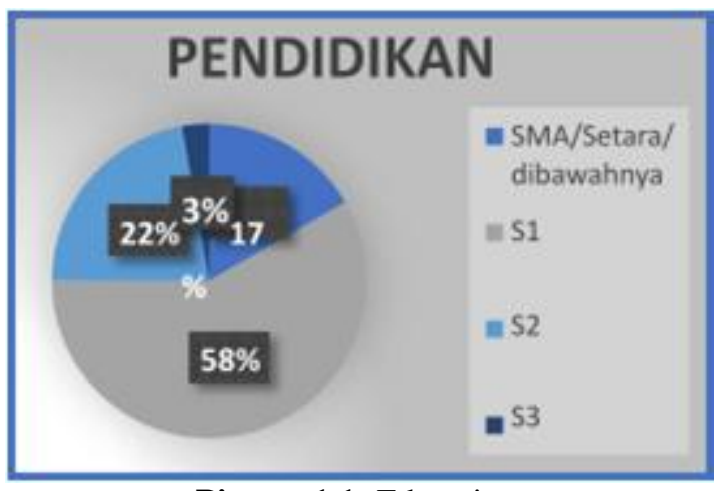

Picture 1.1: Education

From the picture above it can be seen that $58 \%$ of respondents who answered had an S1 education and 22\% had a $\mathrm{S} 2$ education.

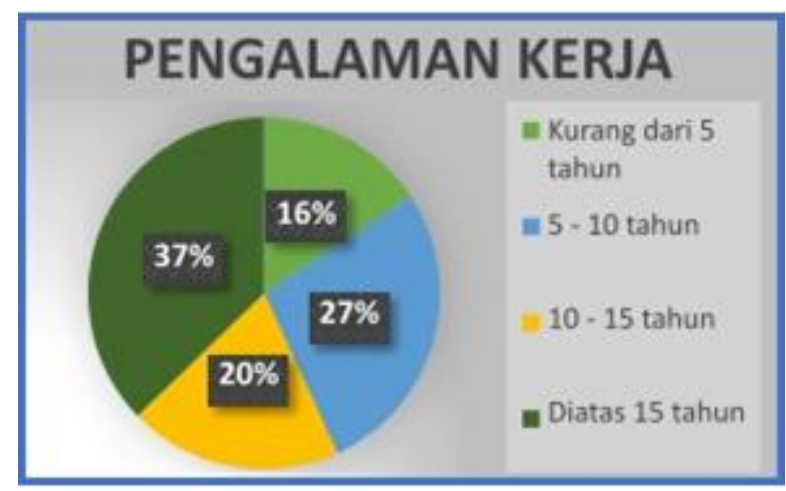

Picture 1.2: Work Experience

From the picture above it can be seen that $37 \%$ of respondents who answered had work experience in their field on average over 15 years and $16 \%$ who had less than 5 years of experience.

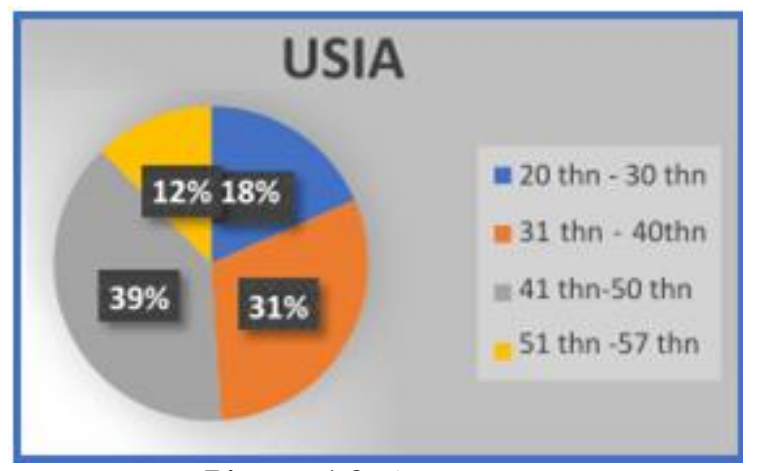

Picture 1.3: Age Factor

From the picture above it can be seen that $39 \%$ of the respondents who answered had an age between 41 - 50 years and $12 \%$ who have the age over 55 years.

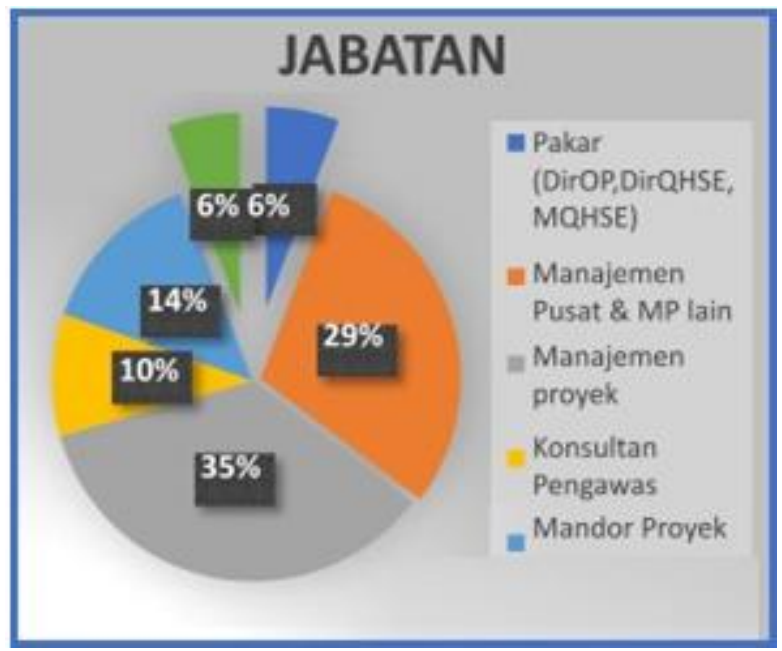

Picture 1.4: Position/Job Desk

From the picture above it can be seen that $35 \%$ of respondents who answered have a position as Project Management between 41 - 50 years and 29\% who have the position of Project Manager.

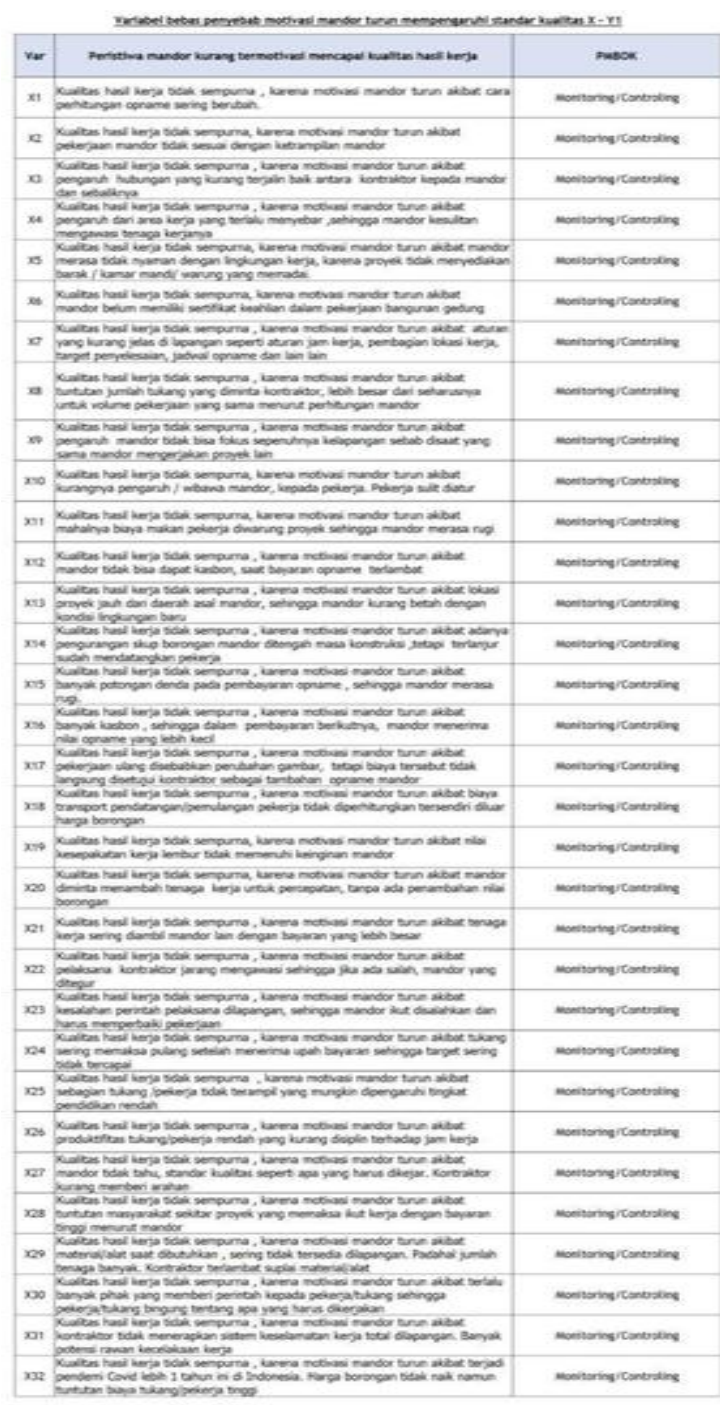

Picture 2 Variables in Variable Statement X 


\begin{tabular}{|c|c|c|}
\hline Var & Peristiwa mandor kurang termotivasi mencapai kualitas hasil kerja & PMBOK \\
\hline $\mathrm{x}_{1}$ & $\begin{array}{l}\text { Kualitas hasil kerja tidak memenuhi persyaratan layak fungsi gedung, karena } \\
\text { motivasi mandor turun akibat cara perhitungan opname sering berubah. }\end{array}$ & Monitoring/Controling \\
\hline$x 2$ & $\begin{array}{l}\text { Kualitas hasil kerja tidak memenuhi persyaratan layak fungsi gedung, karena } \\
\text { motvasi mandor turun akibat pekerjaan mandor tidak sesual dengan ketrampilan } \\
\text { mandor }\end{array}$ & Monitoring/Controling \\
\hline$x_{3}$ & 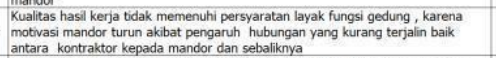 & Monitoring/Controling \\
\hline$x_{4}$ & 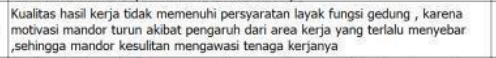 & Monitoring/Controling \\
\hline$x_{5}$ & 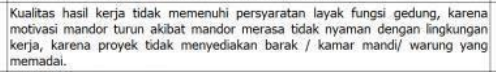 & Monitoring/Controling \\
\hline$x_{6}$ & $\begin{array}{l}\text { Kualitas hasil kerja tidak memenuhi persyaratan layak fungsi gedung, karena } \\
\text { motvasi mandor turun akibat mandor belum memiliki sertifikat keahlian dalam } \\
\text { pekerjaan bangunan gedung }\end{array}$ & Monitoring/Controling \\
\hline$x 7$ & 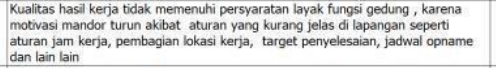 & Monitoring/Controling \\
\hline$x_{8}$ & 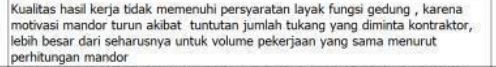 & Monitoring/Controling \\
\hline$x 9$ & 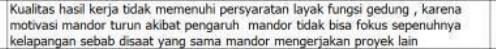 & Monitoring/Controling \\
\hline$x 10$ & 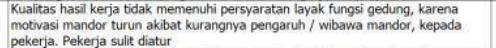 & Monitoring/Controling \\
\hline$x 11$ & 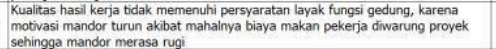 & Monitoring/Controling \\
\hline$x_{12}$ & $\begin{array}{l}\text { Kualitas hasil kerja tdak memenuti persyaratan layak fungsig gedungi, karena } \\
\text { motvisas imandor turun akibat mandor tidak bisa dapat kasbon, saat bayaran } \\
\text { opname terlambat }\end{array}$ & Monitoring/Controling \\
\hline $\mathrm{x} 13$ & 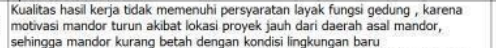 & Monitoring/Controling \\
\hline $\mathrm{x} 14$ & 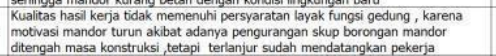 & Monitoring/Controling \\
\hline $\mathrm{x} 15$ & 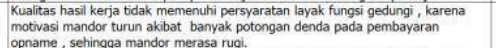 & Monitoring/Controling \\
\hline $\mathrm{x}_{16}$ & 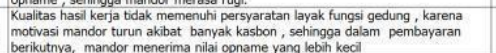 & Monitoring/Controling \\
\hline $\mathrm{x} 17$ & 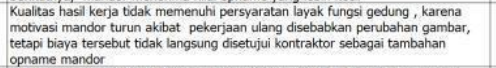 & Monitoring/Controling \\
\hline $\mathrm{x} 18$ & $\begin{array}{l}\text { Kualitas hasis kerja tidak memenuhi persyaratan layak fungsi gedung, karena } \\
\text { motvasis mandor turun akikab tiaya transport pendatangan/pemulangan pekerja } \\
\text { tidak diperhitungkan tersendiri diluar harga borongan }\end{array}$ & Monitoring/Controling \\
\hline $\mathrm{x} 19$ & 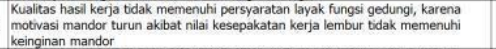 & Monitoring/Controling \\
\hline$x_{20}$ & 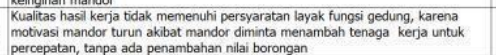 & Monitoring/Controling \\
\hline$x 21$ & $\begin{array}{l}\text { Kualitas hasil keja tidak memenuhi persyaratan layak fungsi gedungi, karena } \\
\text { motvisas imandort turun akibat tenaga kerja sering diambil mandor lain dengan } \\
\text { bayaran yang lebinh besar }\end{array}$ & Monitoring/Controling \\
\hline$x_{22}$ & $\begin{array}{l}\text { Kualitas hasis kejja tidak memenuhi persyaratan layak fungsi gedung, karena } \\
\text { motivasi mandor turun akikabt pelaksana kontraktor jarang mengawasi sehingga } \\
\text { jika ada salah, mandor yang ditegur }\end{array}$ & Monitoring/Controling \\
\hline$x 23$ & $\begin{array}{l}\text { Kualitas hasil keja tdak memenuhi persyaratan layek fungsi gedungi, karena } \\
\text { motivasi mandor turun akibat kesalahan perintah pelaksana dilapangan, sehingga } \\
\text { mandor ikut disalahkan dan harus memperbaiki pekeriaan }\end{array}$ & Monitoring/Controling \\
\hline$x_{24}$ & 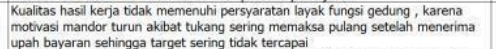 & Monitoring/Controling \\
\hline$\times 25$ & 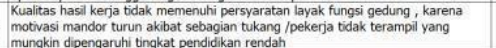 & Monitoring/Controling \\
\hline $\mathrm{x} 26$ & $\begin{array}{l}\text { Kualitas hasil kerja bidak memenuhi persyaratan layak fungsi gedung, karena } \\
\text { motivasi mandor turun akibat produktiftas tukang/pekerja rendah yang kurang } \\
\text { disiplin ternadap jam keria. }\end{array}$ & Monitoring/Controling \\
\hline x27 & 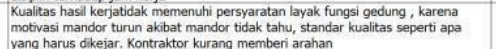 & Monitoring/Controling \\
\hline$x 28$ & 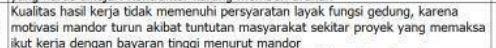 & Monitoring/Controling \\
\hline$\times 29$ & 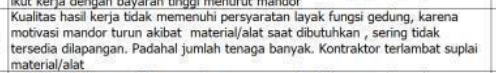 & Monitoring/Controling \\
\hline$\times 30$ & 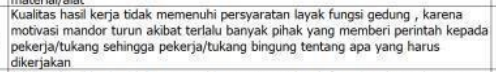 & Monitoring/Controling \\
\hline$x_{3}$ & $\begin{array}{l}\text { Kualiasash hasil kerja tidak memenuhi persyaratan layak fungsi gedung, karena } \\
\text { motivasi mandor turun akibat kontraktor tidak menerapkan sistem keselamatan } \\
\text { kerja total dilapangan. Banyak potensi rawan kecelakaan kerja }\end{array}$ & Monitoring/Controling \\
\hline$\times 3$ & 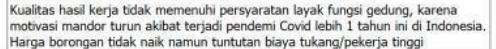 & Monitoring/Controling \\
\hline
\end{tabular}

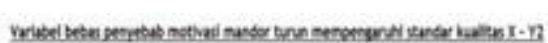

\begin{tabular}{|c|c|c|}
\hline ver & 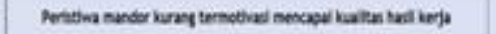 & masor \\
\hline$n$ & 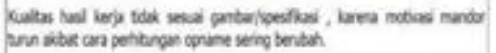 & nenorinyicoetving \\
\hline n & 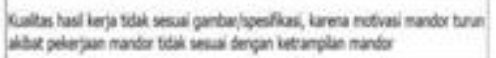 & Monkoring Cortosing \\
\hline 0 & 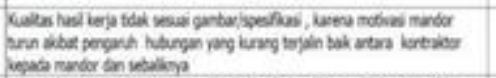 & Nobiboring tonteving \\
\hline$x$ & 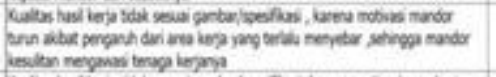 & Meetaringtartueny \\
\hline$\pi$ & 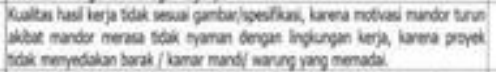 & Nonitoriny Conteiliny \\
\hline $\mathrm{s}$ & 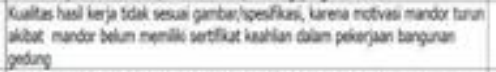 & Mentoring/Tontusing \\
\hline$\pi$ & 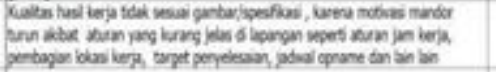 & Nonboriny/Contesing \\
\hline $\mathbf{a}$ & 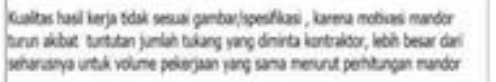 & Mentoring/Contsily \\
\hline$n$ & 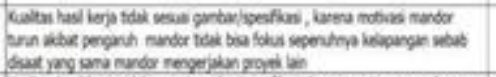 & Meeitoring \\
\hline $\mathbf{n} 6$ & 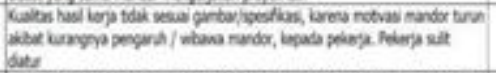 & 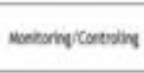 \\
\hline $\mathrm{nt1}$ & 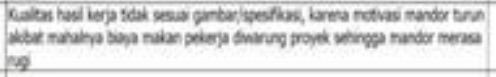 & montoring/Contesing \\
\hline$\times 12$ & 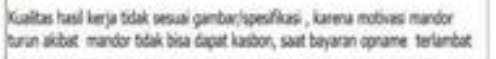 & monitoring/contuing \\
\hline xis & 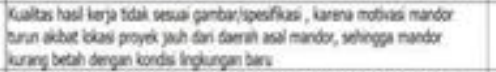 & Mceiboring/Centusing \\
\hline II4 & 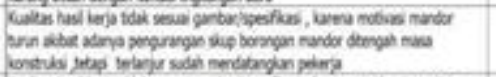 & wetariny \\
\hline$x 15$ & 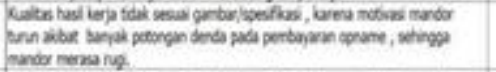 & Noeboring/Contesing \\
\hline X16 & 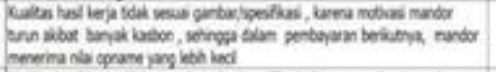 & weboriny/coneving \\
\hline सा7 & 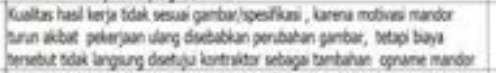 & Meetoring/tontusing \\
\hline $\mathrm{n} \mathbf{8}$ & 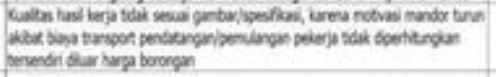 & weetoring/Corteving \\
\hline ns & 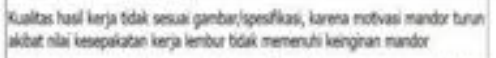 & Woetoring/Contesing \\
\hline 60 & 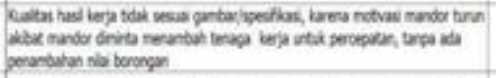 & mentoring/tontsing \\
\hline$n 1$ & 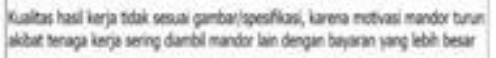 & Mceitoring/Contsing \\
\hline$m$ & 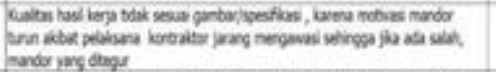 & verenoring/Contesing \\
\hline n & 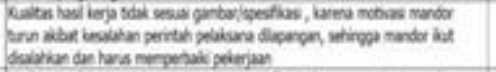 & Nontering icontesing \\
\hline 84 & 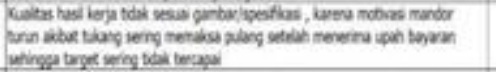 & worbona/coreving \\
\hline es & 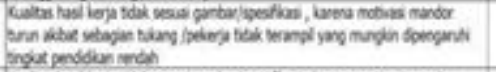 & Metioning/Contising \\
\hline at & 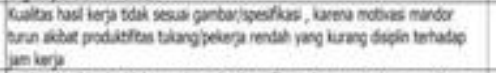 & wonoring/contusing \\
\hline$g$ & 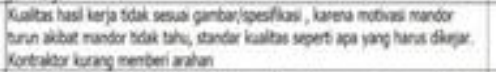 & nontoring/Contsing \\
\hline as & 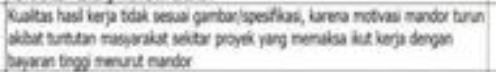 & mentoring/Contusing \\
\hline $\mathrm{xg}$ & 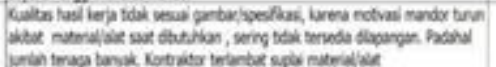 & Meetaring/Contsing \\
\hline$\infty$ & 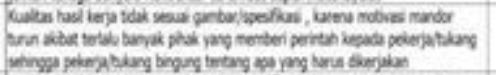 & 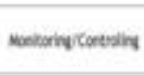 \\
\hline 1 & 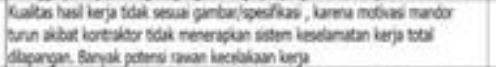 & wontoring/torteing \\
\hline 2 & 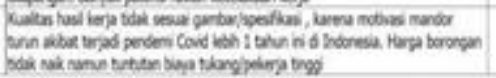 & 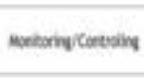 \\
\hline
\end{tabular}

Questionnaire results - dependent variables that affect to the foreman's motivation and quality standards. 
Correlation Analysis and Interrelational Analysis

Correlation method calculation will be selected dependent variables that have a positive relationship with the variable related to the original from 32 selected variables to 6 variables and have a medium to very high correlation value. In the 6 dependent variables that have a normal distribution consisting of variable X7 - (Lack of clear working hours rules, location division, settlement target, schedule), X14 (reduction of scope of Borongan foreman in the middle of construction), X20 - (demand for additional power for acceleration without additional costs), X24 - (workers often force home after receiving payment so that the target is not achieved), X29 - (materials / tools when needed, often not available on the ground, so many workers are unemployed) and X32 - (due to pandemic Covid in a period of 1 year, price does not increase but high job demands).

\section{Regression Analysis}

Results obtained after several regression analysis process by eliminating outliers then it can be that for regression analysis variable $\mathrm{X}$ against $\mathrm{Y} 1$ has a result of $\mathrm{R}$ square $=0.8324$ and Adjusted R Square $=0.8201$; For linear regression analysis is carried out against a combination of determinants that have been established and produced multiple regression models:

$Y=-0,388+0,148 . X 14+0,493 . X 24+0,466 \times 29$

Kesimpulan:

Variable X14 memiliki hubungan positif dengan Variabel Y1 Variabel X24 memiliki hubungan positif deng

Variabel X29 memiliki hubun

Regression analysis variable $\mathrm{X}$ against $\mathrm{Y} 2$ has the result of $\mathrm{R}$ square $=0.91325$ and Adjusted R Square $=0.9068$; For linear regression analysis is carried out against a combination of determinants that have been established and produced multiple regression models:

$Y=-0,395+0,214 . X 20+0,444 . X 29+0,471 \times 32$

Kesimpulan:

Variabel X20 memiliki hubungan positif dengan Variabel Y2 Variabel X29 memiliki hubungan positif dengan Variabel Y2 Variabel X32 memiliki hubungan positif dengan Variabel Y2

Regression analysis variable $\mathrm{X}$ against $\mathrm{Y} 3$ has a result of $\mathrm{R}$ square $=0.9999$ and Adjusted R Square= 0.9999; For linear regression analysis is carried out against a combination of determinants that have been established and produced multiple regression models:

$\mathrm{Y}=\mathrm{-} \mathrm{0,026}+\mathbf{0 , 0 0 5 8} . \mathrm{X} 7+\mathbf{1 , 0 3 6 .} \mathrm{X32}$

\section{Validity Test}

Variable $\mathrm{X}$ is declared valid or not, it can be seen from the value $r$ calculate or $P$ value. Variable $X$ is declared valid if the calculated $\mathrm{r}$ coefficient is greater than the $\mathrm{r}$ table or the $\mathrm{P}$ value coefficient is greater than the significance level of $5 \%$. Based on the value obtained from the value of the $r$ table with the average is 0.279 .

\section{Reliability Test}

Reliability test for variable $\mathrm{X}$ effect with Variable $\mathrm{Y} 1$ : Cronbach's Alpha $=0.95>\mathrm{R}-$ table $=0.279$, then variant $\mathrm{X}$ data, consistent and reliable. Reliability test for variable $\mathrm{X}$ effect with Variable Y1: Cronbach's Alpha $=0.95>\mathrm{R}$ table $=0.279$, then variant $\mathrm{X}$ data, consistent and reliable For the influence of variable $\mathrm{X}$ with variable Y2; Cronbach's Alpha $=0.96>\mathrm{R}-$ table $=0.279$, then variant $\mathrm{X}$ data, consistent and reliable and for the influence of variable $\mathrm{X}$ with variable Y3; Cronbach's Alpha $=0.979>\mathrm{R}-$ table $=$ 0.279 , then variant $\mathrm{X}$ data, consistent and reliable.

\section{Research Discussion Analysis}

The decreased motivation of the foreman in a project needs to be controlled by the contractor management team. This should not happen if the project is faced with the project condition that is timely completed quite short "Fast Track", then there should be no decrease in the funnel foreman motivation because it greatly affects efforts to achieve quality Work Results Standards (Q - Pass).

To understanding of PMBOK (Project Management Book of Knowledge) in the high - rise building projects implementation is absolutely implemented. Especially the understanding of the application of Project Stakeholder Management, Project Communication Management, Project Procurement and Supply Chain Management, by looking at events that cause the foreman motivation to go down, means less Project Stakeholder implementation. Project managers need to prepare a comprehensive plan of a project shared to all stakeholders understanding. As part of the stakeholders, the foreman needs to be built and directed early before the foreman carries out the work (early awareness).

\section{Conclusion}

The results was a strong influence between the decrease in the foreman motivation during the construction implementation, with the non - achievement of Quality Standards on the project completion.

This is in accordance with the research hypothesis, namely if the foreman's work motivation drops during the project, it will affect to the final quality results that it does not reach the Quality Standard (Q - Pass) ".

The regression equation obtained is:

1) In the Quality Pass definition is "Customer Satisfaction", obtained a large relationship between The Foreman Motivation with Simultaneous Quality is $82.01 \%$, and the equation models $\mathrm{Y} 1=-0.388+0.148$. $\mathrm{X} 14+0.493$. X24 + 0.466. X29. The most influential X variants of the X29 and X24 are $81.06 \%$ and $80.49 \%$.

2) In Quality Pass definition is the "Performance to Customer Requirement", obtained a large relationship between The Foreman Motivation with Simultaneous Quality $90.68 \%$, and the equation Y2 $=-0.395+0.214$ $\mathrm{X} 20+0.444$. X29+0.471. X32. And the most influential $X$ variants X32 and X29 by $90.79 \%$ and $88.90 \%$.

3) In Quality Pass definition is "Fitness for Use", obtained a great relationship between Motivation Foreman with Simultaneous Quality 99.99\%, and equation Y3 = $0.026+0.058 . \mathrm{X} 7+1,036 . \mathrm{X} 32$. And the $\mathrm{X}$ variant is the most influential X32 at $80.98 \%$.

4) The results is a strong influence between the motivation 
of the foreman down, with the achievement of quality standards, amounting to an average of $\mathbf{8 4 \%}$ and for the Project Manager that can be a handle in the project control to be mitigated as not to be a big risk in the project completing.

\section{References}

[1] UU no.13 Tahun 2003 Tentang Ketenagakerjaan

[2] UU no.2 Tahun 2017 Tentang Jasa Konstruksi

[3] Permenaker No.06/Men/1985 Tentang Perlindungan Pekerja Harian Lepas

[4] AV 1941 "Algemene voorwarden voor de uitvoering bij aanneming van openbare werken"

[5] Amri Gunasti (2017), Penilaian Kinerja Tukang dan Harapan Mandor dalam proyek Konstruksi, Jurnal Penelitian IPTEKS Universitas Muhammadiyah Jember

[6] Pito Sumarno (2016), Construction Extension to the PMBOK Guide, Project Management Institute

[7] FIDIC (2007) - Persyaratan Kontrak untuk Pelaksanaan Konstruksi - MDB Harmonised Edition

[8] Abdul Razak Rumane (2007), Quality Management in Construction Projects, CRC Press

[9] WIKA - BG - PDDANLAT - IK - 03 (2017), Instruksi Kerja Perolehan Pengadaan Barang dan Jasa, Prosedur Mutu PT Wika Gedung Tbk

[10] WIKA - BG - PDDANLAT - IK - 04 (2017), Instruksi Kerja Evaluasi Penyedia Jasa, Pemasok dan Mandor, Prosedur Mutu PT Wika Gedung Tbk 